The Comma, Polygonia c-album (Linnaeus, 1758), ranges across Europe and temperate Asia to Japan and south to Morocco as various geographical subspecies. The species is distributed within OPEN ACCESS the Indian region from Pakistan, Afghanistan, India (Jammu \& Kashmir to Sikkim), Nepal and Bhutan (Kehimkar 2008), and is represented there by three subspecies: Polygonia c-album kashmira Evans, 1932 (Kashmir, Ladakh); Polygonia c-album cognata Moore, 1899 (northwestern Himalaya); and Polygonia c-album agnicula Moore, 1872 (Nepal-Bhutan). This paper reports the sighting of Polygonia c-album agnicula from Tawang District, Arunachal Pradesh on 10 July 2013. This subspecies has not been reported previously from eastern Himalaya in northeastern India and hence this record adds to its known range in western Arunachal Pradesh. However, it is pertinent to note that Tawang District shares a border with Bhutan, and hence this additional record is not surprising, especially given the lack of Lepidoptera surveys in this area.

In contrast to the other two subspecies within the Indian region, Polygonia c-album agnicula is a rare butterfly (Evans 1932). It was reported as uncommon in Bhutan (Poel \& Wangchuk 2007) and also listed from the Sankosh River catchment, Bhutan by Singh (2012). It was also considered as rare in Nepal (Smith

\section{Notes on the Eastern Comma Polygonia C-ALBUM AGNICULA MOORE, 1872 (LEPIDOPTERA: NyMPHALIDAE: NYMPHALINAE) FROM TAWANG DISTRICT, ARUNACHAL PRADESH, INDIA}

\author{
Monsoon Jyoti Gogoi ${ }^{1}$, Bharat B. Bhatt ${ }^{2}$ \& \\ Anupam Sarmah ${ }^{3}$
}

\footnotetext{
${ }^{1}$ Bokakhat East Dagaon, Disrict-Golaghat, Assam 785612, India ${ }^{2}$ Research officer, PCCF Office, Arunachal Pradesh ${ }^{3}$ Head, Assam Landscapes ,WWF India ,Tezpur, Assam ${ }^{1}$ monsoonjyoti@gmail.com (corresponding author), ${ }^{2}$ sangobarta@gmail.com, ${ }^{3}$ anupamsarmah@gmail.com
}

1989). Gupta \& Shukla (1988) did a survey in western Arunachal Pradesh but did not record it, nor was it included in the list of butterflies from this area published by Betts (1950). Hence, the sighting of this subspecies in this area is significant. The butterfly (Image 1) was photographed sitting on a rock in an open patch of forest at Jang Waterfall, Tawang District $\left(27^{0} 35^{\prime} 20.89^{\prime \prime} \mathrm{N}\right.$ \& $91^{\circ} 59^{\prime} 5.63^{\prime \prime} \mathrm{E}$; Image 3 ) at an elevation of $2240 \mathrm{~m}$. It flew away after it had been observed for a minute.

Polygonia c-album is generally tawny above with black spots, and on the underside of hindwing there is a central silver dash or comma (Evans 1932). The spring and summer forms are often different in tone (Kehimkar 2008). The subspecies, Polygonia c-album agnicula
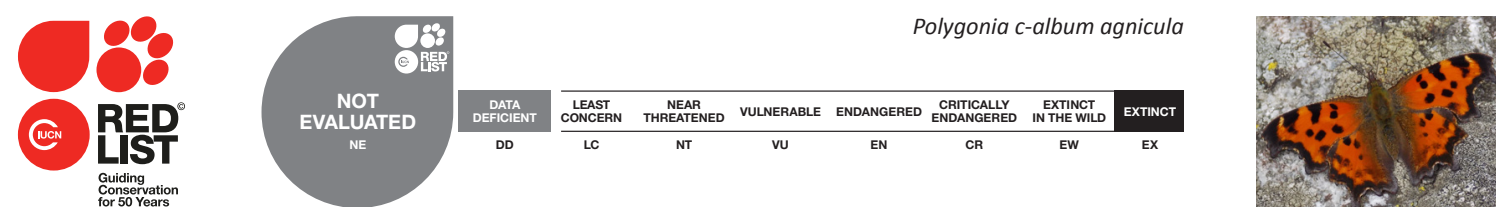

DOI: http://dx.doi.org/10.11609/JoTT.03775.7836-8 | ZooBank: urn:Isid:zoobank.org:pub:827E1B6B-6402-4297-820A-3F97117BD71C

Editor: lan J. Kitching, Natural History Museum, London, UK.

Date of publication: 26 September 2015 (online \& print)

Manuscript details: Ms \# 03775 | Received 13 September 2013 | Final received 02 September 2015 | Finally accepted 05 September 2015

Citation: Gogoi, M.J., B.B. Bhatt \& A. Sarmah (2015). Notes on the Eastern Comma Polygonia c-album agnicula Moore, 1872 (Lepidoptera: Nymphalidae: Nymphalinae) from Tawang District, Arunachal Pradesh, India. Journal of Threatened Taxa 7(11): 7836-7838; http://dx.doi.org/10.11609/JoTT.03775.7836-8

Copyright: (C) Gogoi et al. 2015. Creative Commons Attribution 4.0 International License. JoTT allows unrestricted use of this article in any medium, reproduction and distribution by providing adequate credit to the authors and the source of publication.

Funding: Department of Environmental Science, NEHU, Shillong.

Conflict of Interest: The authors declare no competing interests.

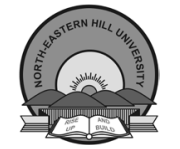

Acknowledgements: We thank Prof. S.K. Barik (NEHU Shillong) for initiating the survey. We also thank the supporting staff who helped us in making the survey successful. We also thank Isaac Kehimkar (BNHS) for allowing us to use his photograph. 


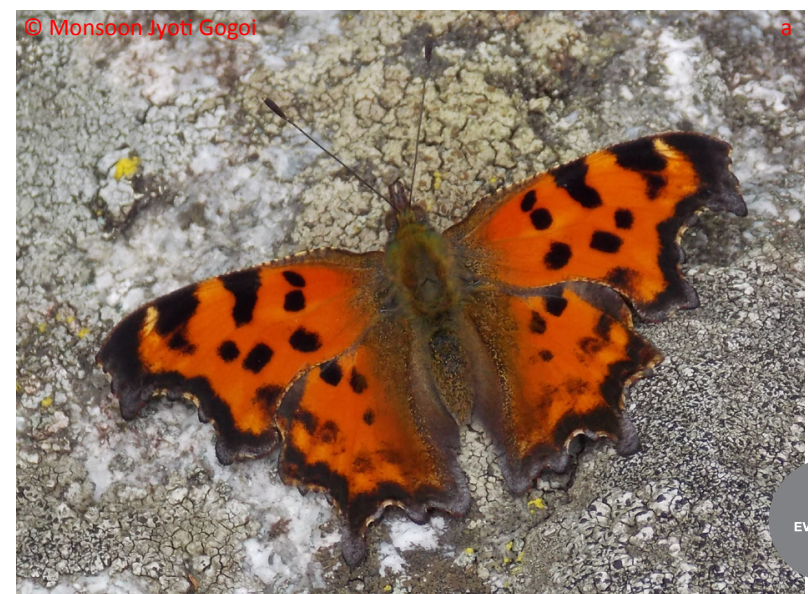

Image 1. Eastern Comma, Polygonia c-album agnicula 10 July 2013, Tawang District, Arunachal Pradesh, India

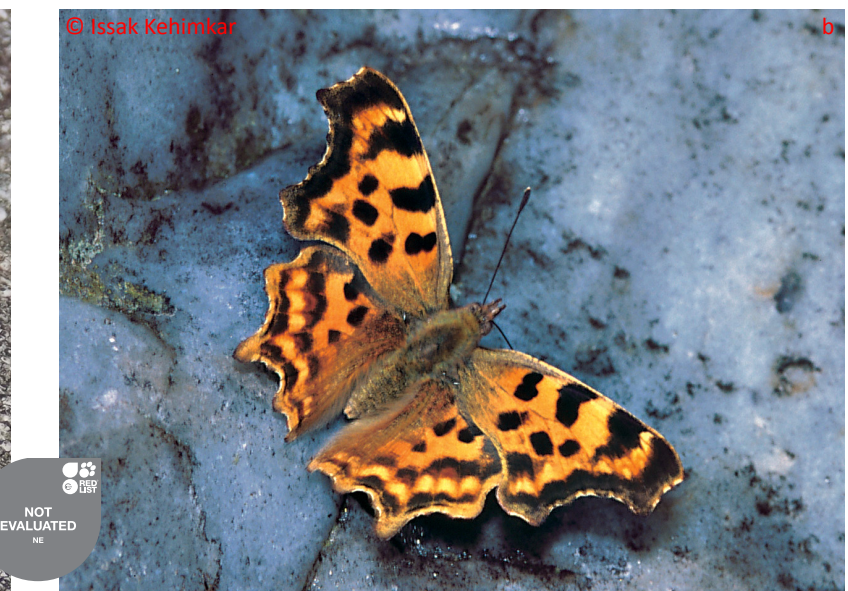

Image 2. Eastern Comma, Polygonia c-album cognata May 2007, Great Himalayan National Park, Himachal Pradesh, India is a more uniform fulvous-red above with narrower markings in comparison with the other subspecies in the Indian region (e.g., Polygonia comma cognata, Image 2). Furthermore, the wing margins above are not as ashy as in the other subspecies, and on the upperside of the hindwing, there are no yellow spots in the submarginal area. Instead, the submarginal area is represented by a red band, bordered along its inner margin by a broken dark brown postdiscal band (Evans 1932).

Polygonia c-album is similar to the Asian Comma,
Polygonia c-aureum (Linnaeus, 1758), the nominotypical subspecies of which is distributed from Myanmar, northern Thailand, Laos, Vietnam, China, Korea and Japan. However, Polygonia c-aureum has a black spot at the base of the discal cell on the upperside of the forewing and on the upperside of the hindwing, the postdiscal black spots have blue centres (Evans 1932).

Little is known about the butterflies of western Arunachal Pradesh. Recently, the western Himalayan species, Heliophorus sena Kollar (Lycaenidae), was

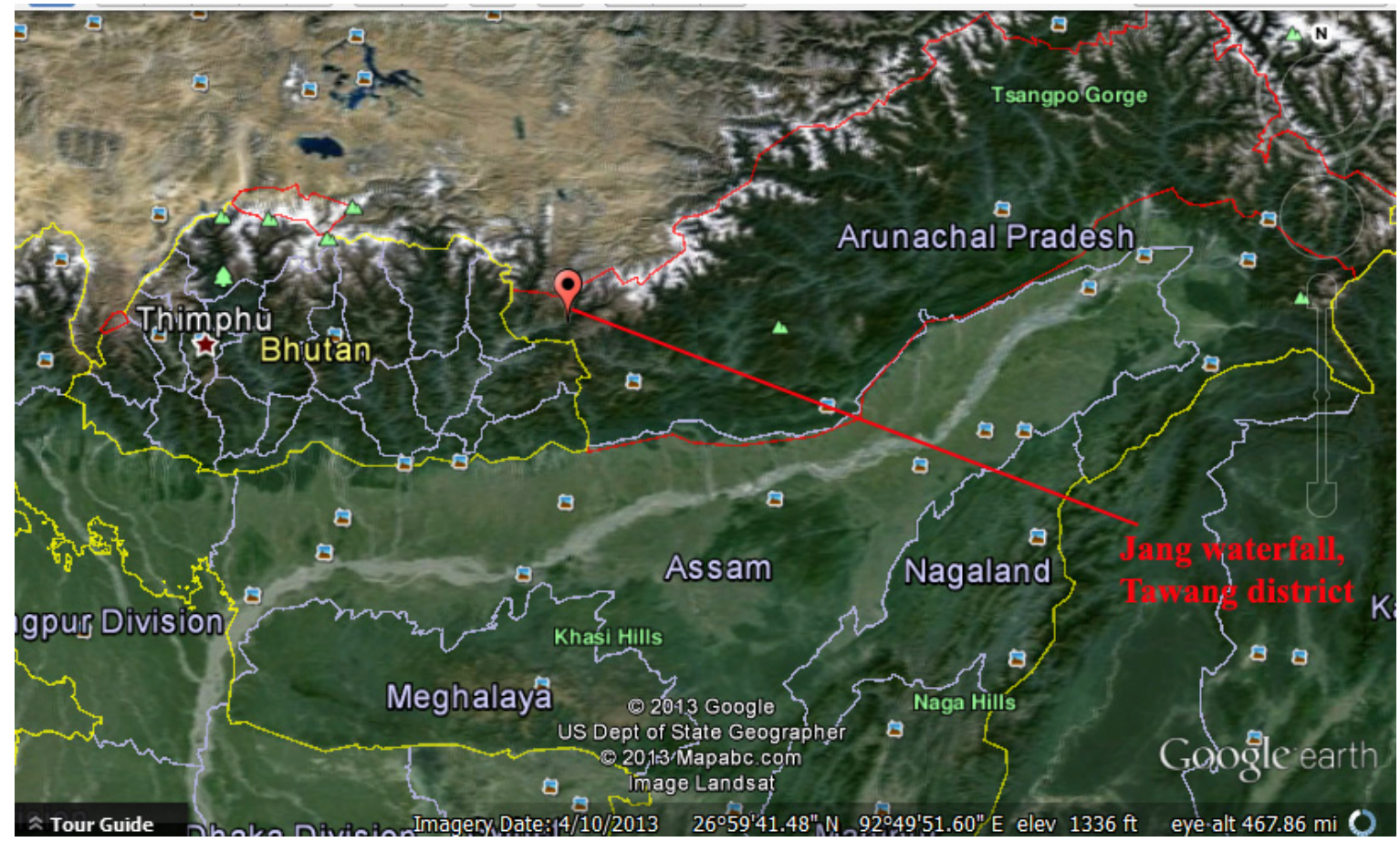

Image 3. Map showing the location of the record of Eastern Comma, Polygonia c-album agnicula from Jhang Waterfall, Tawang District, Arunachal Pradesh, India 
reported from Rupa, Arunachal Pradesh, India (Greeshma 2010) and this species has also occasionally been seen by the first author in the same area in May (unpublished data 2010). This, together with the report herein of Polygonia comma, shows that more butterfly surveys are needed in western Arunachal Pradesh, especially the Tawang District, to document fully the butterfly fauna of this area.

\section{References}

Betts, F.N. (1950). On a collection of butterflies from the Balipara Frontier Tract and the Subansiri area (northern Assam). Journal of the Bombay Natural History Society 49(3): 488-502.

Evans, W.H. (1932). The Identification of Indian Butterflies - 2nd Edition. Bombay Natural History Society, Bombay, $x+454 p p+32 p l$.

Greeshma, M. (2010). On the presence of Aglais cashmirensis Kollar (Nymphalidae) and Heliophorus sena Kollar (Lycaenidae) in Rupa, Arunachal Pradesh, India. Journal of Threatened Taxa 2(9): 11651166; http://dx.doi.org/10.11609/JoTT.o2384.1165-6

Gupta, I.J. \& J.P.N. Shukla (1988). Studies on the butterflies of Arunachal Pradesh and adjoining areas, India Lepidoptera: Acraeidae, Satyridae, Nymphalidae, Riodinidae, and Lycaenidae. Records of the Zoological Survey of India Occasional Paper 109: $1-115$.

Kehimkar, I. (2008). The Book of Indian Butterflies. Bombay Natural History Society and Oxford University Press, New Delhi, xvi+497pp.

van der Poel, P. \& T. Wangchuk (2007). Butterflies of Bhutan. Mountains, Hills and Valleys Between 800 and $3000 \mathrm{~m}$. Royal Society for Protection of Nature (RSPN), Thimphu, Bhutan, 71pp.

Singh, A.P. (2012). Lowland forest butterflies of the Sankosh River catchment, Bhutan. Journal of Threatened Taxa 4(12): 3085-3102; http://dx.doi.org/10.11609/JoTT.o2625.3085-102

Smith, C. (1989). Butterflies of Nepal (Central Himalayas). Craftman Press, Bangkok, 352pp. 